\title{
PRO BONO LEGAL AID BY ADVOCATES: GUARANTEE OF JUSTICE FOR THE POOR
}

\author{
Chairani Azifah \\ Faculty of Law, Universitas Negeri Semarang, Indonesia \\ *Email: chairani.azifah@gmail.com
}

The implementation of legal aid is a manifestation of Indonesia as a legal state that guarantees the human rights of citizens to equality before the law which is guaranteed in the 1945 Constitution. Within the framework of implementing this citizen's human rights, the provision of free legal aid is required among other things to advocates based on Article 22 Law on advocates and their implementing regulations. From this, two formulations of the problem were made as follows: What is the juridical review of the provision of pro bono legal aid? And what is the role of advocates in providing pro bono legal aid?This research is based on normative legal research, which is a research conducted by reviewing and analyzing legal materials and legal issues related to the problems studied. The results of the author's discussion found that free legal aid is the right of the poor to obtain the same justice as other communities, so that the protection of their rights is well fulfilled and the principle of equality before the law. Advocates are obliged to provide free legal aid

The Indonesian Journal of International Clinical Legal Education DOI: https://doi.org/10.15294/ijicle.v3i4.48281

Submitted: Dec 12, 2020 Revised: March 13, 2021 Accepted: August 10, 2021 Available online at https://journal.unnes.ac.id/sju/index.php/iccle (c) 2021 Authors. This work is licensed under a Creative Commons AttributionShareAlike 4.0 International License (CC BY-SA 4.0). All writings published in this journal are personal views of the authors and do not represent the views of this journal and the author's affiliated institutions. 


\section{Chairani Azifah}

to justice seekers, and to obtain free legal assistance, justice seekers must submit a written application to an advocate organization or legal aid institution.

Keywords: Legal Aid; Advocate; Justice; Poor Community

\section{INTRODUCTION}

Article 1 paragraph (3) of the 1945 Constitution explicitly stipulates that the State of Indonesia is a state of law. The principle of the rule of law demands, among other things, the guarantee of equality for everyone before the law (equality before the law). The 1945 Constitution also stipulates that everyone has the right to recognition, guarantees, protection and legal certainty. ${ }^{1}$

In a rule of law, the state recognizes and protects individual rights. Recognition of individual rights is guaranteed under the principle of equality before the law. If there is equality before the law (equality before the law), then there is equal treatment for everyone. Equality before the law guarantees access to justice. One form of access to justice is the guarantee of access to advocates, meaning that if people are able to appoint lawyers to defend their interests, the poor also have the right to be defended by lawyers or public defenders from legal aid organizations. Obtaining a defense from an advocate or defenderis a human right of every person and is one of the elements to obtain justice for all. ${ }^{2}$

The implementation of legal aid is a manifestation of Indonesia as a legal state that guarantees the human rights of citizens to equality before the law which is guaranteed in the 1945 Constitution. Within the framework of implementing this citizen's human rights, the provision of free legal aid is required among other things to advocates based on Article 22 Law on advocates and their implementing regulations. In practice, the interest of advocates is still low in carrying out the obligation to provide free legal aid and reporting.

In the legal system, the principle of legal fiction applies, meaning that everyone is considered to have known the law. The principle of the rule of law, which gives the highest status to the law, postulates that no one should not deny the validity of the law, regardless of their position and power. Everyone, in relation to other people, the state and society,

Moh. Mahfud MD, 2000, "Human Rights Law Politics in Indonesia”, Jurnal Hukum Vol. 7. No.4, p. 2.

2 Supriadi, 2006, Ethics and Responsibilities of the Legal Profession in Indonesia, Jakarta: Sinar Graphic, p. 57. 
will almost certainly experience legal problems. In this case, everyone has the right to defend themselves or get legal assistance. ${ }^{3}$

As an effort to enforce a fair legal process in the justice system in Indonesia, the issue of law enforcement and assistance has a very important role. For this reason, in enforcing the law, it is required to have law enforcement officers who are mentally tough and have high moral integrity, so that they are not only able to enforce the law, but also justice. Likewise, the existence of legal aid in the criminal justice system is expected to participate in assisting the fair and impartial judicial process, so that the objectives of law in Indonesia can be realized. If this is the case, then the problems faced today are no longer just problems of formal legality, interpretation, and application of the articles of a legal regulation, but more than that. ${ }^{4}$

In line with Law Number 8 of 1981 concerning the Criminal Procedure Code, which regulates the rights of suspects or defendants in facing trials, who are given the right to use legal aid services (lawyer/advocate/legal advisor) and choose their own lawyer/advocate/advisor. the law.

Article 54, which reads: "For the sake of defense, a suspect or defendant is entitled to legal assistance from one or more legal advisers during the period and at every level of examination, according to the procedure specified in this law". Then Article 55 states that the suspect or defendant has the right to choose his own legal advisor. Providing legal assistance to poor justice seekers is the obligation of every advocate. The provision of free legal aid is referred to as "probono publico". Legal aid in the probono concept includes four elements, namely: 1) Covers all works in the legal area; 2) Volunteer ; 3) Free; and 4) For underrepresented and vulnerable communities. This obligation is an advocate's moral responsibility as an honorable profession (officium nobbile).

The appointment of an advocate which is regulated through the Supreme Court circular No. 047/TUN/III/1989 completely regulates various provisions, starting from the admission process, the implementing committee, determining the requirements for candidate applications, examination materials, to the role and involvement of professional organizations. advocate. ${ }^{5}$

The appointment of advocates that tend to be restrictive and selective is viewed from the requirement to attend special education for the advocate profession and an internship of at least 2 (two) years continuously at the advocate's office. Whereas previously, these two requirements were not absolutely owned by a prospective advocate.

3 AusAID, YLBHI, PSHK \& IALDF, 2009, Guide to Legal Aid in Indonesia, Jakarta: Indonesia Obor Foundation, p. 33.

4 Bambang Sunggono \& Aries Harianto, 1994, Legal Aid and Human Rights, Bandung: Mandar Maju, p. 2.

5 Yudha Pandu, 2004, Clients and Advocates in Practice, Jakarta: PT. Eternal, p. 33. 


\section{Chairani Azifah}

Lawyers or advocates are officially appointed based on a decree from the Minister of Justice. In the Big Indonesian Dictionary explains that; Advocates are legal experts who are authorized to act as advisers or defenders of cases in court (lawyers). And according to Law No. 18 of 2003 concerning Advocates, an Advocate is a person whose profession is to provide legal services, both inside and outside the court, who meet the requirements based on the provisions of this law.

Before the enactment of Law Number 18 of 2003 concerning advocates, the implementation or enforcement of the code of ethics for advocates in Indonesia was very difficult. Because there are various advocate organizations, each of which has its own code of ethics, there is no obligation for advocates to join advocate organizations, and there is no prohibition for advocates to enter or change advocate organizations. ${ }^{6}$

Advocates are obligated to provide free legal aid to citizens who cannot afford it (Article 22 of the Law on Advocates). This is a form of devotion for advocates in carrying out their profession as an element of law enforcement officers. Cases that can be requested for legal assistance include cases of:criminal, civil, state administration, and military crimes.

Basically, advocates who refuse to provide free legal aid can be subject to sanctions. Likewise, advocates who are not wholehearted or half-hearted in providing legal assistance may be subject to sanctions. The imposition of sanctions on advocates will be carried out through examination of complaints received by advocate organizations or advocates' honorary council. ${ }^{7}$

Based on the above background, two problem formulations were made as follows:

1. What is the juridical review of the provision of pro bono legal aid?

2. What is the role of advocates in providing pro bono legal aid?

The research method is a system and an absolute process that must be carried out in a research and scientific development activity. Legal research is a scientific activity based on certain methods, systematics, and thoughts that aim to study a certain legal phenomenon by analyzing it. ${ }^{8}$

6 Hadi Herdiansyah et al, 2004, Code of Ethics for Indonesian Advocates, Jakarta: PSHK, p. 37. Advocates in defending their clients must adhere to the principle of Equality before the Law, namely the guarantee of equality before the law and the principle of Presumption of Innocence, which is to assume that their clients are correct based on the data and information provided to them. This principle is implemented so that in his defense, an advocate dares to carry out his profession and functions effectively. See also Addy Candra, and Dwikari Nuristiningsih. "Peran Advokat Terhadap Hubungan Korban Dengan Kejahatan dan Peradilan Pidana." Masalah Keadilan Vol. 19 No.1, 2019, pp. 1-10; Mochamad Mansur, "Peran Advokat dalam Pembangunan Hukum Indonesia." Widya Yuridika: Jurnal Hukum Vol. 2 No. 2, 2019, pp. 57-70; Hibnu Nugroho, "Peran Advokat dalam Mewujudkan Peradilan yang Berintegritas." Diktum: Jurnal Ilmu Hukum Vol. 7 No.1, 2019, pp. 1-12.

7 Ausaid, YLBHI, PSHK, Op. Cit, p. 45.

8 Zainuddin Ali, 2009, Legal Research Methods, Jakarta: Sinar Graphic, p. 18. 
This research is based on normative legal research, which is a research conducted by reviewing and analyzing legal materials and legal issues related to the problems studied. Legal research is carried out to solve problems that arise, while the results to be achieved are in the form of a description of what should be done to answer these problems.

The legal sources used in this study consist of Primary Legal Materials, namely legal materials that are authoritative, meaning that these legal materials have authority, which consist of statutory regulations related to legal aid and advocates. In this study, the legislation as primary legal material is Law Number 18 of 2003 concerning Advocates, Law Number 16 of 2011 concerning Legal Aid and Government Regulation Number 43 of 2013 concerning Terms and Procedures for Providing Legal Aid and Fund Distribution Legal Aid.

Then secondary legal materials, including all publications on law that are not official documents. Publications about this law include books, as well as legal opinions from experts published in journals.

\section{JURIDICAL OVERVIEW OF THE PROVISION OF PRO BONO LEGAL AID}

In Indonesia's positive law, the matter of legal aid has been regulated in Article 250 of the Herziene Indische Regulation (HIR). According to this article, advocates are asked for legal assistance if there is a request from the accused person and is threatened with the death penalty. Thus Article 250 HIR does not oblige advocates to provide legal assistance to persons accused of or threatened with the death penalty. Article 250 of the HIR, is also more directed at those who are of European/Dutch citizenship. This article is full of elements of racial discrimination. Although the practice of HIR is limited, the regulation can be interpreted as the beginning of the institutionalization of legal aid into our positive law.

As a legal state based on Pancasila and the 1945 Constitution, to provide protection to the community, it is necessary to have a professional legal service provider institution which is expected to be able to provide justice, truth, legal certainty, and the rule of law to clients in particular and the community seeking justice in general. ${ }^{9}$

However, both in Government Regulation No. 83 of 2008 concerning Legal Aid, advocates are required to provide free legal aid to justice seekers, and to obtain free legal assistance, justice seekers must submit a written application to an advocate organization or legal aid institution. Meanwhile, legal aid itself is not a right that needs to be asked for or a right that is given, but a basic right in human rights guaranteed

9 Arief T. Surowidjojo, 2004, Legal Reform, Jakarta: Faculty of Law, University of Indonesia, p. 124. 


\section{Chairani Azifah}

by the state listed in the constitution, as well as the right to life and the right to defend life.

Meanwhile, according to Law Number 16 of 2011 concerning Legal Aid and according to Government Regulation No. 42 of 2013 concerning Terms and Procedures for Providing Legal Aid and Distribution of Legal Aid Funds, Legal Aid is legal services provided by Legal Aid Providers free of charge to Legal Aid Recipients.

The guarantee of constitutional rights has not received adequate attention so that the establishment of Law Number 16 of 2011 concerning Legal Aid (UUBH) becomes the basis for the state to guarantee citizens, especially for poor people or groups of people, to get access to justice and equality before the law. ${ }^{10}$ In addition, there is also Law Number 18 of 2003 concerning Advocates which in its provisions requires an advocate or legal adviser to provide legal assistance to underprivileged communities free of charge based on the conditions stipulated in the Act. If the advocate does not carry out his duties to provide legal assistance to the underprivileged, then the advocate will be subject to sanctions in accordance with the applicable law.

In accordance with the constitutional demands, Article 22 of Law Number 18 of 2003 concerning Advocates, hereinafter referred to as the Advocate Law, has accommodated that advocate are "obligated" to provide free legal assistance to justice seekers who cannot afford it. This principle is a derivative of the principle of the rule of law (rechtstaat) and the principle of equality before the law in the 1945 Constitution, namely Article 27 paragraph (11) which states that every citizen is equal before the law with no exceptions, and Article 28D paragraph (1) which "Everyone has the right to recognition, guarantee, protection and fair legal certainty and equal treatment before the law". ${ }^{11}$

In Law Number 4 of 2004 concerning Judicial Power in article 37, it is stated that everyone who is involved in a case has the right to obtain legal assistance. In providing legal assistance, advocates or legal advisors help facilitate the settlement of cases by upholding Pancasila, law and justice. $^{12}$

There are two terms related to legal aid, namely legal aid and legal assistance. The term legal aid is usually used to show the meaning of legal aid in a narrow sense, namely the provision of services in the legal field to someone involved in a case for free, especially for those who cannot afford it. While the notion of legal assistance is used to show the

10 Yusuf Saefudin, 2015, "Implementation of Legal Aid for the Poor in Central Java Based on Law Number 16 of 2011 concerning Legal Aid," Journal of Legal Idea Vol. 1 No. 1, p. 65-66.

11 Philipus M Hadjon, 1987, Legal Protection for the People in Indonesia, Bandung: Bina Ilmu, p. 176.

12 HA Mukti Arto, 1996, Practice of Civil Cases at the Religious Courts, Yogyakarta: Pustaka Pelajar, p. 50. 
meaning of legal aid in a broad sense, because in addition to legal assistance for those who are unable, there is also legal aid provided by lawyers who use honoraria or receive payment of a sum of money from clients. ${ }^{13}$

However, in reality there are still many advocates who do not want to provide free legal aid because the regulations regarding the provision of free legal aid are not binding on every advocate. The obligation to provide legal assistance should have binding consequences for the advocate. So if an advocate is not willing to carry out these obligations, then they must have ethical consequences. Even though so far, the code of ethics has not emphasized the obligation to provide legal aid by every advocate, it has become a gap for advocates to avoid providing legal aid.

Considering that legal aid may only be provided by an advocate, it is appropriate that every advocate must carry it out as well as possible. Moreover, considering that the advocate profession is a respectable profession, it should provide legal services for those who need it.

Article 14 of Law Number 16 of 2011 concerning Legal Aid stipulates that to obtain legal aid, the applicant must meet the following requirements: ${ }^{14}$

a. submit a written application containing at least the identity of the applicant and a brief description of the subject matter for which Legal Aid is being requested.

b. submit documents relating to the case; and

c. attach a certificate of poverty from the lurah, village head, or an official at the same level as the legal aid applicant's place of residence.

d. Legal aid is also a legal service that aims to provide legal protection and defense of the human rights of the suspect/defendant since he is detained until a permanent court decision is obtained. What is defended and given legal protection is not the fault of the suspect/defendant but the human rights of the suspect/defendant in order to avoid dishonorable treatment and actions or arbitrary actions from law enforcement officials. ${ }^{15}$

Legal aid is a human right of every citizen, both for citizens who can afford it and those who are classified as poor. When a capable person (the have) has a legal problem, he can appoint one or more advocates to defend his interests. Likewise, a person who is classified as incapable (the have not) can request a defense from one or more public defenders from legal aid institutes to defend their interests in a legal case. it is unfair

13 Sukinta, 1997, The Role of Legal Aid Institutions for the Community in Obtaining Justice, Semarang: Faculty of Law, Diponegoro University, p. 4.

14 Mohammad Yasin \& Herlambang Perdana, 2014, Guide to Legal Aid in Indonesia, Jakarta: Indonesia Obor Foundation, p. 481

15 HMA Kuffal, 2004, Application of the Criminal Procedure Code in Legal Practice, Malang: UMM Press, p. 158. 


\section{Chairani Azifah}

if only people who can afford it are defended by an advocate in facing legal problems, while the poor do not get a defense because they are unable to pay an advocate's fee. ${ }^{16}$

The guarantee to appoint an advocate or public defender must apply to all cases and not only as regulated in Article 56 of the Criminal Procedure Code, which states that for criminal acts that require a sentence of fifteen years or more or are required to be sentenced to death, while for suspects or defendants who are classified as poor Legal assistance can only be given free of charge if it is threatened with a criminal sentence of five years or more. This is in order to ensure that everyone can obtain the maximum defense of an advocate or public defender in order to ensure the implementation of a fair judicial process (due process of law).

The government then formed the Instruction of the Minister of Justice of the Republic of Indonesia No. M 01-UM.08.10 of 1996, concerning Guidelines for the Implementation of Legal Aid Programs for Underprivileged Communities Through Legal Aid Institutions Instruction of the Minister of Justice of the Republic of Indonesia No. M 03UM. 06.02 of 1999, concerning Guidelines for the Implementation of Legal Aid Programs for Underprivileged Communities Through District Courts and State Administrative Courts.

In addition, it is also regulated in the Circular of the Director General of the General Courts and State Administrative Courts No. D.Um.08.10.10 dated May 12, 1998, concerning JUKLAK Implementation of Legal Aid for Poor People.

Law No. 18 of 2003 concerning advocates clearly states the requirements to be appointed as an advocate. This is explained in article 2 paragraph (1) which provides general requirements that "those who can be appointed as advocates are graduates with a legal higher education background and after attending special education for advocates carried out by the organization". Furthermore, the general requirements described in Article 2 paragraph (1) are described in more detail in Article 3 paragraph (1) which states that "to be appointed as an advocate one must meet the following requirements:

a. Citizens of the Republic of Indonesia;

b. Domiciled in Indonesia;

c. Not status as a Civil Servant or state official;

d. Be at least 25 (twenty five) years old;

e. Holds a bachelor's degree with a legal higher education background as referred to in Article 2 paragraph (1);

f. Pass the exam held by the advocate organization;

g. Internship for at least 2 (two) years continuously at an advocate's office;

16 Frans Hendra Winata, 2009, Pro Bono Publico Constitutional Rights of the Poor to Obtain Legal Aid, Jakarta: Publisher PT Gramedia Pustaka Utama, p. 1. 
h. Never been convicted of a criminal offense punishable by imprisonment of 5 (five) years or more;

i. Behave well, be honest, responsible, fair, and have high integrity.

People who know about the intricacies of the law are expected to be able to help those who do not understand the law, because people who have never been in contact with the courts and have had a case, usually they will be nervous about facing the law, so an assistant or representative is very useful ${ }^{17}$. Legal assistance provided by an advocate is not only beneficial for litigants, but also provides enormous assistance to judges in examining a case, because they are able to contribute ideas in resolving cases relating to law that arise both in the environment and in the community. courts and in the general public.

\section{THE ROLE OF ADVOCATES IN PROVIDING PRO BONO LEGAL AID}

Basically, advocate comes from Latin, namely "advokatus" which means a legal expert who provides assistance or assistance in legal matters, this assistance or assistance is giving advice as good services, in its development it can then be requested by anyone. who need or need to have proceedings in law. ${ }^{18}$

The word advocate is etymologically derived from the Latin advocare which means to defend, to call one, said to vouch or warrant. In English advocate means to speak in favor of or depend by argument, to support, indicate, or recommended publicly. ${ }^{19}$ Article 1 point 13 of Law Number 8 of 1981 concerning the Criminal Procedure Code states that a legal advisor is a person who meets the requirements determined by or based on the law to provide legal assistance. The Law on Advocates provides the definition of an advocate as a person whose profession is to provide legal services, both inside and outside the court, who meet the requirements based on the provisions of this Law.

An advocate is a jurist, a legal expert from a law degree. So, even though an expert on law is not a law graduate, then he cannot be said to be an advocate, but can only be said to be a lawyer, that's because a lawyer may not be a law scholar, but he is a legal expert. An advocate in addition to providing legal advice to his client, he is also directly responsible for the defense of the case, and represents his client in proceedings and resolving cases that are submitted by clients to the court. An advocate is a person who represents his client to take legal action

17 Sudikno Mertokusumo, 2002, Indonesian Civil Procedure Code, Yogyakarta: Liberty, p. 18.

18 Lasdia Wlas, 1989, Cakrawala Advokat Indonesia, Yogyakarta: Liberty, p. 4.

19 Rahmat Rosyadi \& Sri Hartini, 2003, Advocates in Islamic Perspectives \& Positive Law, Jakarta: Ghalia Indonesia, p. 72. 


\section{Chairani Azifah}

based on a power of attorney given for defense, prosecution at trial proceedings in court. ${ }^{20}$

Indonesian advocates have long wanted legitimacy. Legitimacy to be recognized for its existence is equal to other court officers such as judges and prosecutors, as law enforcers. After decades of struggle for Indonesian advocates to seek legitimacy, hope began to emerge when the government and the House of Representatives began to seriously discuss the draft Law on advocates, which finally on April 5, 2003, was enacted Law No. 18 of 2003 on Advocates. ${ }^{21}$

An advocate in providing legal assistance is in accordance with the orders of the advocate law and the legal aid law, in which the advocate profession is one of the independent law enforcers in order to place justice above all else, in providing free legal aid to people seeking justice. is one of the obligations of lawyers. The obligation to provide free legal aid is also strengthened in Law no. 18 of 2003 concerning advocates. In article 22 paragraph (1) it states: "Advocates are obliged to provide legal assistance free of charge to justice seekers who cannot afford it". ${ }^{22}$

Thus, the position and role of the advocate becomes very important in the law enforcement process, both inside the court (litigation) and outside the court (non-litigation). Especially after the issuance of Law Number 18 of 2003 concerning advocates, there is a great hope from the public, academics, and practitioners to eliminate discrimination in the law enforcement process. ${ }^{23}$

In the implementation of Legal Aid, Law No. 16 of 2011 concerning Legal Aid has a purpose in providing legal aid, namely as stated in Article 3 of Law No. 16 of 2011 concerning Legal Aid, namely:

a. Guarantee and fulfil the right to receive Legal Aid to get access to justice;

b. Realizing the constitutional rights of every citizen in accordance with the principle of equality in law;

c. Ensuring certainty that the implementation of Legal Aid is carried out evenly throughout the territory of the Republic of Indonesia; and

d. Realizing an effective, efficient, and accountable judiciary.

The role of advocates in providing legal assistance to justice seekers is indeed very important, in accordance with law number 18 of 2003 article 22 which states that advocates are obliged to provide free legal aid to justice seekers who cannot afford, this is the main basis for every advocate to actively play a role in providing legal assistance to

20 Rahmat Rosyadi \& Sri Hartini, 2003, Advocates in Islamic Perspectives and Positive Law, Jakarta: Ghalia Indonesia Member of IKAPI, p. 72.

21 Munir Fuady, 2005, Ethics of the Legal Profession, Noble Profession, Bandung: Citra Aditya Bakti, p.14.

22 Ropaun Rambe, 2001, Advocate Practice Techniques, Bandung: Grasindo, p. 8.

23 Febri handayani, 2015, "Juridical Review of the Role of Advocates in Assisting Clients in Divorce Cases at the Pekanbaru City Religious Court", Journal of Islamic Law, Vol. 15 No. June 1, 2015, p. 34. 
people in need. In the legal aid law number 16 of 2011 article 5, the applicant for legal aid submits an application for legal aid to the legal aid provider, then the legal aid provider within a maximum period of 3 (three) working days after the legal aid application is declared complete must provide an answer accepting or refuse a request for legal assistance. In the event that the application for legal assistance is accepted, Legal Aid Providers provide legal assistance based on a special power of attorney from the Legal Aid Recipient. In the event that the application is rejected, the Legal Aid Provider shall state the reasons for the refusal.

One of the efforts to realize justice or equality in law is the existence of legal assistance for every citizen involved in legal cases. According to Soerjono Soekanto, legal aid basically means legal assistance provided by experts for citizens who need to realize their rights and also get reasonable legal protection. ${ }^{24}$

In fighting for the interests of his clients, an advocate carries out his duties none other than to uphold justice, use and legal certainty. he is always in touch and oriented to the struggle for humanity, and not just defending cases because he receives an honorarium. The profession of an advocate is certainly different from a businessman who is looking for profit to get the maximum profit from the business being run. The advocate profession is a profession that prioritizes the understanding that the advocate profession is within the scope of ethical activities that value the existence of an honorable professional position, scientific understanding and morally measurable actions. ${ }^{25}$

The role of advocates in Law No. 18 of 2003 concerning Advocates. In carrying out the function of an advocate, it is necessary to have an independent advocate profession, meaning that in carrying out his profession defending the community in fighting for justice and legal truth does not get pressure from any party. The freedom of the advocate profession must be guaranteed and protected by law, so that its status and position in society is clear so that it can function optimally.

PAdvocate profession seems to be increasingly strategic, and all advocate behavior is increasingly important in Indonesia, which claims to be a state of law. According to Article 22 paragraph 1 of the LawLaw Number 18 of 2003 concerning Advocates, stated that advocates function to provide free legal assistance for suspects or defendants who are unable to uphold human rights, so that they are not treated arbitrarily, so that advocates can benefit the poor who seek justice and protection of their rights, but in reality what happens in society is not all advocates have a high social value, there are still advocates who favor money and power, so the benefits of having an advocate in providing free legal aid for the

24 IGN. Ridwan Widyadharma, 2010, Legal Professionals in Providing Legal Aid, Semarang: Diponegoro University Publishing Agency, p. 26.

25 Kelik Pramudya \& Ananto Widiatmoko, 2010, Guidelines for Professional Ethics of Law Apparatus, Yogyakarta: Yustisia Library, p. 93. 


\section{Chairani Azifah}

poor are to uphold Human rights are felt to have not functioned optimally and comprehensively.

The implementation of law in society is very dependent on the legal awareness of a society because humans are legal subjects. However, apart from depending on the legal awareness of the community, it also depends and is largely determined by the implementation of law enforcement by law enforcement officers. Therefore, many legal regulations cannot be implemented properly because law enforcers do not understand how to carry out their duties and responsibilities. ${ }^{26}$

The duties and responsibilities of an advocate and must be considered in handling a case are as follows: ${ }^{27}$

a. Uphold the code of professional ethics;

b. Guiding and protecting clients from worldly and hereafter disasters in order to find truth and justice that satisfy all parties, in accordance with legal, moral and religious values;

c. Assist in the creation of a simple, fast and low-cost judicial process, as well as the achievement of a final case settlement;

d. Respect the judiciary and the judicial process in accordance with legal, religious and moral norms;

e. Protecting his client from the tyranny of other parties and protecting him from doing wrong to other parties;

f. Hold fast to the trust given by his client with full responsibility both to his client, himself, law and morals, as well as to God Almighty;

g. Provide periodic reports and explanations to clients regarding the tasks entrusted to them;

h. Avoiding various forms of covert blackmail against his clients;

i. Be sympathetic and feel what the client is suffering and even prioritize the interests of his clients over his personal interests;

j. There must be a trusting and trustworthy relationship between a lawyer or an advocate and his client so that they do not harm and harm each other;

k. Carry out professional duties as a legal service provider to act honestly, fairly, and responsibly based on law and justice;

1. Advocates are also obliged to provide free legal aid for clients who cannot afford it, this is in accordance with Supreme Court Decision No. 5/KMA/1972 concerning groups that are obliged to provide legal assistance.

Advocates have a working principle which is then referred to and reduced to the Advocate Professional Code of Ethics. The code of ethics is then used as the basis for an advocate in carrying out their activities as legal advisers, legal counsel and law enforcers in accordance with what

26 Abdurrahman, 1980, Various Problems in Law Enforcement Practices in Indonesia, Bandung: Alumni, p. 14.

27 Mukti Arto, 2001, Seeking Justice (Criticism of Solutions to the Practice of Civil Justice in Indonesia), Yogyakarta: Pustaka Pelajar, p. 133-134. 
is stated in Article 26 of Law Number 18 of 2003 concerning Advocates that: ${ }^{28}$ "To maintain the dignity and honor of the advocate profession, a code of ethics for the profession of advocate and advocate organization has been prepared. So advocates must comply with and comply with the code of ethics of the advocate profession and the provisions concerning the Honorary Council of Advocates' Organizations".

\section{CONCLUSION}

This free legal aid is the right of the poor to get the same justice as other people, so that the protection of their rights is well fulfilled and the principle of equality before the law is not only a myth for the poor, but in fact justice Law in Indonesia is not easy to obtain, especially for the poor, so they still feel that there is a different treatment in seeking justice between the rich and the poor, as well as legal protection that is still perceived as less favorable to the poor, so that their rights are still vulnerable to various violations. by the rulers. Until now, equality before the law or justice for all has not been felt by all levels of society equally. It is hoped that in the future the policies of advocate organizations related to pro bono will be more focused. It takes commitment and an active role of advocate organizations to further encourage pro bono. The provision of pro bono legal aid needs to be encouraged and encouraged. Steps such as socializing pro bono implementation provisions for advocates and the wider community need to be further encouraged. Finally, monitoring and evaluating pro bono implementation by advocate organizations so that pro bono services can be more documented and measurable is important. Certainty regarding the use of pro bono time for advocates needs to be regulated or not, it is important if advocate organizations are serious about making pro bono programs an effort to contribute to advocate organizations in realizing justice for the poor and underprivileged.

\section{REFERENCES}

Abdurrahman, A. (1980). Aneka Masalah Dalam Praktek Penegakan Hukum di Indonesia. Bandung: Alumni.

Ali, Z. (2009). Metode Penelitian Hukum. Jakarta: Sinar Grafika.

Arto, H. A. M. (1996). Praktek Perkara Perdata pada Pengadilan Agama. Yogyakarta: Pustaka Pelajar.

Arto, M. (2001). Mencari Keadilan (Kritik Solusi terhadap Praktik Peradilan Perdata di Indonesia). Yogyakarta: Pustaka Pelajar.

28 Supriadi, 2006, Ethics and Responsibilities of the Legal Profession in Indonesia, Jakarta: Sinar Graphic, p. 87. 


\section{Chairani Azifah}

Candra, A., \& Nuristiningsih, D. (2019). Peran Advokat Terhadap Hubungan Korban Dengan Kejahatan dan Peradilan Pidana. Masalah Keadilan, 19(1), 1-10.

Fuady, M. (2005). Etika Profesi Hukum. Profesi Mulia, Bandung: Citra Aditya Bakti.

Hadjon, P. M. (1987). Perlindungan Hukum Bagi Rakyat di Indonesia. Bandung: Bina Ilmu.

Handayani, F. (2015). Tinjauan Yuridis Terhadap Peranan Advokat dalam Mendampingi Klien dalam Perkara Perceraian di Pengadilan Agama Kota Pekanbaru. Hukum Islam, 15(1), 61-82.

Herdiansyah, H., et.al. (2004). Kode Etik Advokat Indonesia. Jakarta: PSHK.

Kuffal, H. M. A. (2004). Penerapan KUHAP Dalam Praktek Hukum. Malang: UMM Press.

Mahfud, M. (2000). Politik Hukum Hak Asasi Manusia di Indonesia. Jurnal Hukum IUS QUIA IUSTUM, 7(14), 1-30.

Mansur, M. (2019). Peran Advokat dalam Pembangunan Hukum Indonesia. Widya Yuridika: Jurnal Hukum,2(2), 57-70. https://doi.org/10.31328/wy.v2i2.1067

Mertokusumo, S. (2002). Hukum Acara Perdata Indonesia. Yogyakarta: Liberty.

Nugroho, H. (2019). Peran Advokat dalam Mewujudkan Peradilan yang Berintegritas. Diktum: Jurnal Ilmu Hukum, 7(1), 1-12.

Pandu, Y. (2004). Klien dan Advokat dalam Praktek. Jakarta: PT. Abadi. Pramudya, K., \& Widiatmoko, A. (2010). Pedoman Etika Profesi Aparat Hukum. Yogyakarta: Pustaka Yustisia.

Rambe, R. (2001). Teknik Praktek Advokat. Bandung: Grasindo.

Rosyadi, R., \& Hartini, S. (2003). Advokat dalam Perspektif Islam dan Hukum Positif. Jakarta: Ghalia Indonesia Anggota IKAPI.

Saefudin, Y. (2015). Implementasi Pemberian Bantuan Hukum Bagi Rakyat Miskin Di Jawa Tengah Berdasarkan Undang-Undang Nomor 16 Tahun 2011 Tentang Bantuan Hukum. Jurnal Idea Hukum, 1(1), 67-76. http://dx.doi.org/10.20884/1.jih.2015.1.1.7

Sukinta, S. (1997). Peranan Lembaga Bantuan Hukum Bagi Masyarakat dalam Memperoleh Keadilan. Semarang: Fakultas Hukum Universitas Diponegoro.

Sunggono, B., \& Harianto, A. (1994). Bantuan Hukum dan Hak Asasi Manusia. Bandung: Mandar Maju.

Supriadi, S. (2006). Etika dan Tanggung Jawab Profesi Hukum di Indonesia. Jakarta: Sinar Grafika.

Surowidjojo, A. T. (2004). Pembaharuan Hukum. Jakarta: Fakultas Hukum Universitas Indonesia. 
Widyadharma, I. G. N. R. (2010). Profesional Hukum Dalam Pemberian Bantuan Hukum. Semarang: Badan Penerbit Universitas Diponegoro.

Winata, F. H. (2009). Pro Bono Publico Hak Konstitusional Fakir Miskin Untuk Memperoleh Bantuan Hukum. Jakarta: Penerbit PT Gramedia Pustaka Utama.

Wlas, W. (1989). Cakrawala Advokat Indonesia. Yogyakarta: Liberty.

Yasin, M., \& Perdana, H. (2014). Panduan Bantuan Hukum di Indonesia. Jakarta: Yayasan Obor Indonesia. 


\section{"When the world is silent, even one voice becomes powerful."}

\section{Malala Yousafzai}

\section{Conflicting Interest Statement}

All authors declared that there is no potential conflict of interest on publishing this article.

\section{Funding}

None

\section{Publishing Ethical and Originality Statement}

All authors declared that this work is original and has never been published in any form and in any media, nor is it under consideration for publication in any journal, and all sources cited in this work refer to the basic standards of scientific citation.

Cite this article as:

Azifah, C. (2021). Pro Bono Legal Aid by Advocates: Guarantee of Justice for the Poor. The Indonesian Journal of International Clinical Legal Education, 3(4),

537-552. https://doi.org/10.15294/ijicle.v3i4.48281 